\title{
Paradigms for parasite conservation
}

\author{
Eric R. Dougherty, ${ }^{*} \dagger \dagger \neq \ddagger$ Colin J. Carlson, ${ }^{*} \ddagger \ddagger$ Veronica M. Bueno, $†$ Kevin R. Burgio, $†$ \\ Carrie A. Cizauskas, $\neq$ Christopher F. Clements, $₫$ Dana P. Seidel, ${ }^{*}$ and Nyeema C. Harris $\rrbracket$
}

${ }^{*}$ Department of Environmental Science, Policy, and Management, University of California, Berkeley, 130 Mulford Hall, Berkeley, CA 94720, U.S.A.

†Department of Ecology and Evolutionary Biology, University of Connecticut, 75 N. Eagleville Road, Storrs, CT 06269, U.S.A. ‡Department of Ecology and Evolutionary Biology, Princeton University, 106A Guyot Hall, Princeton, NJ 08544, U.S.A. §Institute of Evolutionary Biology and Environmental Studies, University of Zurich, Winterthurerstrasse 190 CH-8057, Zurich, Switzerland

ๆEcology and Evolutionary Biology, University of Michigan, 830 North University Avenue, Ann Arbor, MI 48109, U.S.A.

\begin{abstract}
Parasitic species, which depend directly on bost species for their survival, represent a major regulatory force in ecosystems and a significant component of Earth's biodiversity. Yet the negative impacts of parasites observed at the host level have motivated a conservation paradigm of eradication, moving us farther from attainment of taxonomically unbiased conservation goals. Despite a growing body of literature bighlighting the importance of parasite-inclusive conservation, most parasite species remain understudied, underfunded, and underappreciated. We argue the protection of parasitic biodiversity requires a paradigm shift in the perception and valuation of their role as consumer species, similar to that of apex predators in the mid-20th century. Beyond recognizing parasites as vital trophic regulators, existing tools available to conservation practitioners should explicitly account for the unique threats facing dependent species. We built upon concepts from epidemiology and economics (e.g., bost-density threshold and cost-benefit analysis) to devise novel metrics of margin of error and minimum investment for parasite conservation. We define margin of error as the risk of accidental bost extinction from misestimating equilibrium population sizes and predicted oscillations, while minimum investment represents the cost associated with conserving the additional bosts required to maintain viable parasite populations. This framework will aid in the identification of readily conserved parasites that present minimal bealth risks. To establish parasite conservation, we propose an extension of population viability analysis for host-parasite assemblages to assess extinction risk. In the direst cases, ex situ breeding programs for parasites should be evaluated to maximize success without undermining bost protection. Though parasitic species pose a considerable conservation challenge, adaptations to conservation tools will belp protect parasite biodiversity in the face of an uncertain environmental future.
\end{abstract}

Keywords: disease ecology, economic valuation, ex situ conservation, food webs, parasitology, population viability analysis

Resumen: Las especies parásitas, aquellas que dependen directamente de las especies hospederas para sobrevivir, representan una gran fuerza regulatoria dentro de los ecosistemas y un componente significativo de la biodiversidad de la Tierra. Aún así, los impactos negativos de los parásitos que se ban observado a nivel del bospedero han motivado un paradigma de conservación enfocado en la erradicación, lo que nos aleja cada vez más de alcanzar objetivos de conservación sin sesgos taxonómicos. A pesar de la creciente bibliografía que resalta la importancia de la conservación incluyente de los parásitos, la mayoría de este tipo de especies sigue siendo poco estudiada, mal financiada y poco valorada. Argumentamos que la protección de la diversidad parasitaria requiere de un cambio en el paradigma de la percepción y valoración de su papel 
como especies consumidoras, similar al de los depredadores primarios a mediados del siglo XX. Más allá de reconocer a los parásitos como reguladores tróficos vitales, las berramientas existentes disponibles para quienes practican la conservación deberían reconocer explícitamente las amenazas únicas que enfrentan las especies dependientes. Partimos de conceptos de epidemiología y economía (p. ej.: umbral de densidad de bospedero y análisis de costo-beneficio) para diseñar medidas novedosas del margen de error y la inversión mínima para la conservación de parásitos. Definimos el margen de error como el riesgo de extinción accidental del bospedero a partir de una mala estimación del tamaño de poblaciones en equilibrio y de los pronósticos de oscilación, mientras que la inversión mínima representa el costo asociado a la conservación de los bospederos adicionales requeridos para mantener viables a las poblaciones de parásitos. Este marco de trabajo ayudará en la identificación de los parásitos conservados inmediatamente que presentan un riesgo sanitario mínimo. Para establecer la conservación de parásitos, proponemos una extensión del análisis de viabilidad poblacional para los conjuntos de bospedero-parásito y así evaluar el riesgo de extinción. En los casos más urgentes, se deberían evaluar programas de crianza ex situ para maximizar el éxito sin debilitar la protección al hospedero. Aunque las especies parásitas presentan un reto considerable para la conservación, las adaptaciones de las herramientas de conservación ayudarán a proteger la diversidad de parásitos de frente a un futuro ambiental incierto.

Palabras Clave: análisis de viabilidad poblacional, conservación ex situ, ecología de las enfermedades, parasitología, redes alimentarias, valoración económica

\section{Introduction}

Conservation is founded on the preservation of biodiversity for the future, but human health, as a rule, always takes precedence. Wildlife management divides biodiversity into threats and targets, and species that conflict with humans are labeled pests rather than priorities. However, the delayed realization that the pest eradication paradigm has unanticipated detrimental effects has forced practitioners to consider alternative approaches. Consequently, conservation is tasked with the identification of the prejudices of earlier paradigms and the restoration of their casualties.

During the mid-19th century, for example, massive declines in herbivore populations on the American prairie forced carnivores to turn to livestock for sustenance, eliciting calls by ranchers and farmers for governmentsponsored extermination (Bergstrom et al. 2013). At its peak, this management effort was responsible for the deaths of an estimated 21,000 wolves annually at the hands of government hunters (Mech \& Boitani 2010). In 1963, under growing pressure from the environmental movement, an advisory group was tasked with reviewing the practices of the program. Upon their recommendations, and based on a growing body of literature on the negative impacts associated with predator removal (Hairston et al. 1960), eradication efforts were supplanted by a predator-inclusive paradigm that values the consumers' role in ecosystems.

Conservationists did not fully appreciate the ecological importance of apex carnivore species until after the decimation of many of these predators's populations on most continents (Berger \& Wehausen 1991). Furthermore, a transformation in the public perception of predators occurred following the extirpation of many species of charismatic megafauna (Kellert et al. 1996; Messmer et al.
1999). These species are now often invoked in conservation efforts as keystone, umbrella, sentinel, flagship, and indicator species due to their ability to directly promote biodiversity in ecosystems through resource facilitation and trophic stabilization (Sergio et al. 2008). Parasites may serve many similar functions, such as providing regular carrion for scavenger assemblages (DeVault et al. 2003) and structuring communities by indirectly affecting multiple trophic levels (Lafferty et al. 2008). A shift in the scientific and public perception of parasites is required as one recognizes not only their intrinsic value, but also their role as trophic regulators. While parasitic species occur in almost every major animal clade, we present the case for rethinking the paradigms used for parasite conservation with a focus on invertebrate macroparasites, such as helminths and lice.

The advantage of apex predators over parasites in facilitating a paradigm shift is their charisma. Today, large carnivores attract huge amounts of funding and their conservation is associated with the idea of protecting large areas (Ray et al. 2013). Parasites, on the other hand, are not often praised for their aesthetic appeal outside the field of parasitology (Gómez \& Nichols 2013; Lafferty 2014). The sperm whale roundworm (Placentonema gigantissima), for example, can grow up to $9 \mathrm{~m}$ in length, yet it is rarely considered alongside its cetacean hosts as one of the more interesting creatures in our oceans.

Parasitism, as a highly specialized life history, is a consistent part of natural ecosystems and has played a proportionate role in driving co-evolutionary radiation. Numerous examples illustrate the incredible diversity of form and function associated with a parasitic life history, including unique adaptations like behavior control, feminization and castration, and unparalleled complexity in life cycles (Poulin 2010). Despite their important role 
on organismal and evolutionary time scales, parasites are frequently equated with disease in current conservation applications, resulting in their eradication for the sake of host preservation. In the best cases, parasites are preserved to protect host immunity in reintroduced populations, as in the case of unique protozoans (identified as Eimeria sp.) in the black-footed ferret (Mustela $n i$ gripes) (Gompper \& Williams 1998). However, in many cases, the extinction or extirpation of obligate parasites is merely a consequence, intended or otherwise, of conserving megafauna hosts, as in the case of the louse Colpocephalum californici of the California condor (Gymnogyps californianus) (Koh et al. 2004) and the louse Rallicola pilgrimi of the little spotted kiwi (Apteryx owenii) (Rózsa \& Vas 2015).

Although the benefits of parasites are an active topic of research, the negative impacts parasites can have, especially on humans, are conspicuous and well documented (Kuris 2012). Unfortunately, even when these costs and benefits of parasites can be measured, comparing them within the same value system is difficult because it is impossible to determine the exchange rate between ecosystem health and human lives. Potential infection of livestock, fishery stocks, or humans by a pathogen may be enough to curtail parasite conservation efforts. For example, Echinococcus granulosus, a generalist tapeworm, is highly prevalent in canid species but is frequently removed from wolves during translocation efforts (Lafferty 2014). The parasite has a more substantial effect on ungulates, altering their behavior and increasing their risk of predation by wolves. Thus, maintaining E. granulosus in the system may be beneficial for reintroduced wolves (Lafferty \& Kuris 2014). The fact that humans and livestock can be accidental hosts of the tapeworm complicates matters because introducing the parasite via wolves may have economic and humanhealth ramifications (Corn \& Nettles 2001). With wolf reintroduction already a contentious issue, conserving a zoonotic pathogen may undermine established conservation goals. Human economic concerns may also warrant parasite eradication, as in cases such as rinderpest, which threatened both wildlife and livestock (Mariner et al. 2012).

While it may be necessary to make exceptions for highly pathogenic or zoonotic parasites of hosts that are charismatic or the subject of high-profile conservation efforts, we encourage examination of the potential risk that the loss of parasite species may pose to hosts in the long run. By definition, parasites are exploitative, but recent research shows the major role they play as catalysts in the evolution of host immunity, particularly through interaction with the major histocompatibility complex (Kamath et al. 2014). In human populations, the hygiene hypothesis suggests that diminished pathogen or parasite exposure, often due to urbanization, has led to a steep increase in the frequency of allergies and autoimmune diseases such as type 1 diabetes and multiple sclerosis (Yazdanbakhsh et al. 2002). Therapies for autoimmune diseases that involve helminths are being developed, such the introduction of whipworms (Trichuris suis) to downregulate a patient's immune response and achieve remission in Crohn's disease (Summers et al. 2005). The immunoregulatory role of parasites is especially important in multispecies systems, where high parasite biodiversity has a dilution effect on chronic infections. Johnson et al. (2013) demonstrated that within-host parasite competition reduces rates of disease transmission in amphibian hosts and results in a concomitant reduction in limb deformations.

As ecological puppeteers, parasites affect major changes at the ecosystem scale under the guise of their host species, making their value significant but difficult to measure (Lefevre et al. 2009). By some metrics, parasites represent the dominant force shaping ecosystems. For example, parasites constitute a large portion of biomass in most systems and can be responsible for up to $78 \%$ of trophic interactions in some food webs (Lafferty et al. 2006). By mediating interactions between free-living species through apparent competition (Hatcher et al. 2012), they may be as important in their regulatory effects as wolves, cougars, or any other apex carnivore. Moreover, behavior-altering parasites may increase the flow of energy throughout trophic levels, where such transfer might not otherwise exist (Kuris et al. 2008). For example, camel crickets (Diestrammena spp.) and grasshoppers (Kinkiconocephalopsis koyasanesis and Psyrana japonica) infected with nematomorph parasites (Gordionus spp.) are 20 times more likely to jump into a stream, where their biomass constitutes up to $60 \%$ of the energy intake of endangered fish populations (Sato et al. 2011). Often, the parasite species that have the greatest ecosystem impacts tend to be small and virulent rather than intrinsically impressive, like the sperm whale roundworm. Thus, competing prioritization schemes based on intrinsic versus functional value are likely to emphasize a different subset of parasites from any given ecosystem.

As studies demonstrating the vital role parasites play in ecosystem health and functionality emerge, we encourage the development of conservation tools that enable practitioners to become more discerning when prioritizing and executing parasite conservation efforts. A shift in mindset is just the first step in preserving these vital elements in many ecosystems; successful parasite conservation requires adapting and expanding the tools available to conservation practitioners. Incorporating parasites into the conservation agenda represents the next step in the iterative process through which conservation has expanded from resource management to the protection of previously maligned and misunderstood consumer species like large carnivores. 


\section{The Conservation Toolbox}

The majority of the methods used in conservation biology were developed without explicitly considering the many dependent species that constitute vital elements of any ecosystem. We propose a series of shifts in the way conservation professionals apply several of their most established tools in order to incorporate parasite species that have been previously overlooked. Most fundamental to this is the identification of the subjects needing protection. Naming species is required for the development of conservation plans, but the rate at which species are described may be overtaken by extinction rates in the direst cases (Costello et al. 2013). Consequently, concurrent to naming and cataloging parasite biodiversity, conservation practitioners are faced with the challenge of rapidly identifying which species are at the greatest risk of extinction.

Parasites face the unique conservation challenge of dependence on a sustainable antagonistic interaction. However, in unstable cases where there is an immediate trade-off between host population health and parasite persistence, eradication of the parasite is often suggested in the hope of preserving the host, despite the cost to ecosystem function and diversity (Fig. 1) (Stringer \& Linklater 2014). In these cases, parasite eradication may even be vital to hosts' survival. For instance, Zhang et al. (2008) report that a host-specific intestinal nematode (Baylisascaris schroederi) is the greatest threat to giant pandas; it accounted for $50 \%$ of mortality during their study. In cases like this, parasite conservation will inevitably upset the public, posing serious ethical challenges.

Recommendations made based on the use of the newly adapted conservation tools should abide by the precautionary principle, particularly concerning issues of human health. Incomplete knowledge of parasite life histories and complex multispecies interactions create the potential for unanticipated consequences; conservation of even the most endangered and intrinsically valuable parasite should be reconsidered if the parasite potentially threatens human health. For example, despite the diversity and unique biological attributes of hemosporidian blood parasites, the conservation of malaria given its global mortality rate is obviously unjustifiable from a human health perspective. Despite these risks, one must not dismiss all zoonotic diseases as lost causes. Rather, one should reduce the odds of mismanagement and the potential for emergence of novel pathogens by including epidemiologists and public health specialists in risk analysis and conservation planning. This way, ecologically important parasites such as Echinococcus granulosus can be protected in a way that maximizes the services they provide to natural ecosystems and minimizes risk to humans. Once the risks have been adequately considered, parasites can be effectively incorporated into the mainstream conservation agenda through their inclusion in economic valuation, population viability analysis, ex situ conservation efforts, and open-source data management databases.

\section{Including Parasites in Economic Valuation}

Parasitic species occupy a unique space in the public's perception of nature. Their negative impacts on human health and economics are particularly salient (Gómez \& Nichols 2013), while their diversity and functional role in ecosystems remain unrecognized by most. Some proponents of economic valuation metrics argue they inherently account for the value of the ecological relationships underlying a threatened or endangered species (White et al. 1997), but it seems unlikely that parasites' ecological role will be thoughtfully considered in any method of appraisal. At the scale of a single interaction, it is difficult to untangle the positive effects a parasite might have from the costs they incur to ecosystem services provided by the host. Measuring the impacts that parasites have on their hosts and trophic webs will likely require manipulative experiments, which may be an infeasible step in conservation planning for already endangered species. Within the time frame dictated by co-extinction rates, it is unlikely that many parasites will be sufficiently studied. If one hopes to use the existing economicvaluation framework to revise policy in the short term, proxy methods, such as metrics of connectedness in networks (Mougi \& Kondoh 2012), may be needed to evaluate their functional roles and assign monetary values.

Previous efforts at disease and parasite eradication offer an idea of the economic cost of the potential alternative to conservation. Complete eradication has proved difficult and costly in the past; smallpox and rinderpest are the only examples of successful campaigns thus far (Barrett 2004; Mariner et al. 2012). For example, approximately US $\$ 350$ million have been spent on the effort to eradicate Guinea worm disease (Dracunculus medinensis), a macroparasite that infected nearly 3.5 million people each year when the effort first began (Callahan et al. 2013). In cases in which human health is not directly affected, maintaining parasite population levels, rather than advocating for increase as one would for most other threatened species, may represent the most cost-effective and acceptable strategy. Evidence from successful maintenance of parasites during captive breeding programs suggests that the costs may actually be negligible for some species (Izdebska 2006).

Thus, we propose shifting efforts away from costly broad-scale eradication efforts, and advocate for a framework that values hosts and parasites as species assemblages to measure their total net economic significance. With imperfect knowledge of host-parasite interactions (HPIs), it may be impossible to accurately 


\begin{tabular}{|c|c|c|}
\hline & Host conserved & Host extinct \\
\hline 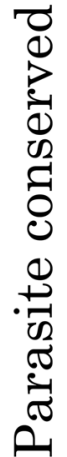 & $\begin{array}{l}\text { Ideal circumstances: both are saved } \\
\text { Charismatic megafauna with vital } \\
\text { highly-specific parasites }\end{array}$ & $\begin{array}{c}\text { OR } \\
\text { Reintroduction into alternative hosts } \\
\text { Rediscovery after host extinction }\end{array}$ \\
\hline 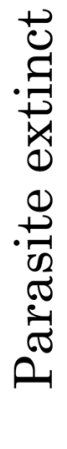 & Current conservation paradigm & $\begin{array}{l}\text { Current paradigm when host } \\
\text { conservation proves unsuccessful }\end{array}$ \\
\hline
\end{tabular}

Figure 1. Four conceivable outcomes for parasite conservation, taken from 4 case studies (clockwise from upper left): co-threatened Gyrostigma rhinocerontis (Oestridae: Diptera) bot-fly parasite introduced to new areas in conjunction with reintroduction efforts for the critically endangered black rhinoceros (Diceros bicornis) (Stringer \& Linklater 2014); louse Columbicola extinctus rediscovered on the Band-tailed Pigeon (Columba fasciata) subsequent to the extinction of the Passenger Pigeon (Ectopistes migratorius) (Clayton \& Price 1999); extinct Rallicola extinctus and its host the buia (Heteralocha acutirostris) (Pizzi 2009); and extinct louse Colpocephalum californici of the currently critically endangered California Condor (Gymnogyps californianus) (Kob et al. 2004). value the independent and interacting effects that each has on the other's ecosystem services. Consequently, we propose the treatment of HPIs as a unit of conservation, maximizing important criteria such as host immunity and intrinsic value, and careful monitoring of added risk stemming from the interaction. We predict that in cases where coevolution and equilibrium population dynamics are important factors, preserving HPIs will be synonymous with effective host conservation.

\section{Including Parasites in Population Viability Analysis}

Population viability analysis (PVA) is a mainstay of conservation biology and has been applied to assess a wide range of taxa (Boyce 1992). In its simplest form, this approach takes population survey data and projects the probability that a population will persist over a given time frame based on variation in the population's growth rate, a starting population size, and some threshold at which extinction is assumed to occur (Dennis et al. 1991). The extinction risk of a population of interest can then be estimated by simulating multiple populations and assessing the number that go extinct over the time frame of interest (typically 100 years).

Currently, the majority of parasite involvement in PVA focuses on the effect of parasite extirpation on host per- sistence odds (Gerber et al. 2005). A simple starting goal for expansion of the concept would be developing tools to adjust the extinction threshold of the host PVA to reflect the minimum population size that an associated parasite species requires to persist. However, applying PVA methods to host or parasite populations alone is insufficient for a framework that considers hosts and parasites as assemblages. Rather than a modified host PVA, we argue that a more dynamic joint approach better accounts for the natural oscillations that characterize antagonistic species interactions. In the simplest case, where a specialist parasite exploits a single host, epidemiological tools such as the host-density threshold and the intrinsic rate of increase can be used to find the sustainable limits of host-parasite equilibrium (Fig. 2). Two metrics that are specific to challenges posed by parasite conservation, and emerge from the phase-space framework, are margin of error (ME) and minimum investment (MI). The former represents the risk of accidental host extinction from misestimating equilibrium population sizes and predicted oscillations. The latter corresponds to the cost associated with conserving the additional hosts required to maintain viable parasite populations. When faced with the divergent choice between eradication and mutual preservation, we argue that the ideal joint PVA has the capacity to measure both the additional investment 


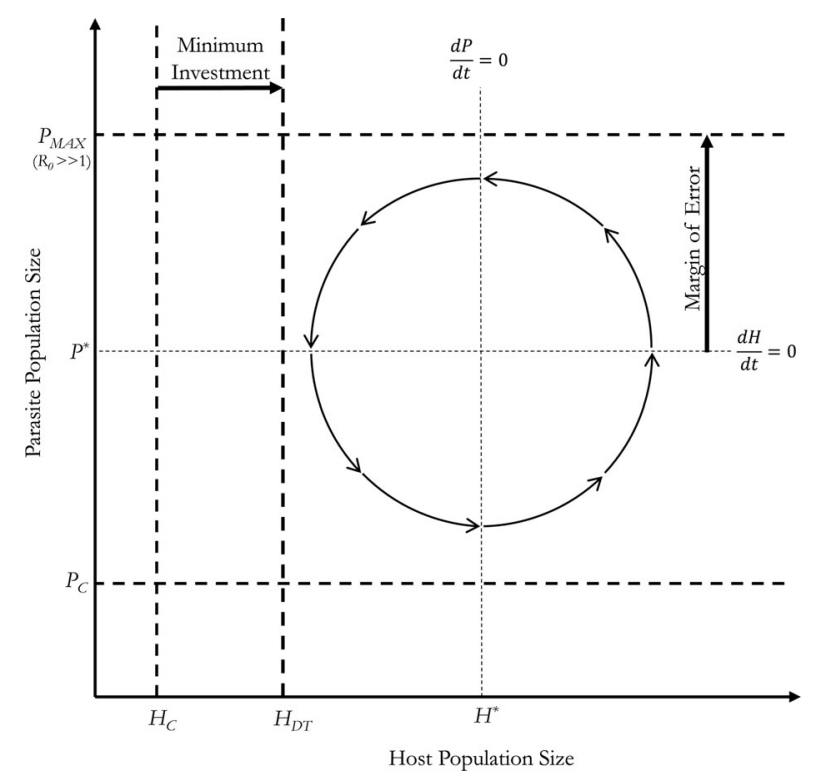

Figure 2. Host-parasite cycles in phase space, illustrating our approach to joint population viability analysis (PVA) in the standard model for bost-parasite dynamics (Anderson \& May 1978).

required to maintain parasites (MI) and the assumed liability for disease-driven host extinction (ME), informing conservation efforts.

The dynamics of generalist parasites within ecosystems are far more difficult to model. In such cases, the odds of parasite persistence are distributed across a set of variably suitable hosts, necessitating a parasite PVA that integrates multiple simultaneous joint PVAs. Conversely, parasites with multistage life cycles or free-living stages can face compounding and distributed risk across each sequential host, which would require an approach that accounts for contact and transmission dynamics between levels (Rudolf \& Lafferty 2011). A solid foundation in system dynamics allows for incorporation of additional corrections, for example, assessing the tradeoffs between parasite costs and benefits both at an individual scale (bolstering host immunity; Johnson et al. 2013) and at a population scale (in regulation of species interactions).

Typically, parasites lack long-term population data, which poses a challenge for fitting dynamical models that accurately measure or estimate demographic and epidemiological parameters. Unlike the approach taken in the U.S. Endangered Species Act of setting a critical population size and adhering to that threshold (Rohlf 1991), parasites will likely require an ongoing periodic reassessment of what constitutes stable populations (and acceptable risk to humans) given current environmental conditions and host densities. However, as the challenge of reintroducing gray wolves into Yellowstone National Park illustrates, it is likely more feasible to expend re- sources to prevent an unpopular species from disappearing in the first place than to try to return it after its disappearance.

\section{Including Parasites in Ex Situ Conservation}

In cases where the conservation status of a host becomes dire enough that the survival of a species is contingent on its removal from the wild and management in captivity (ex situ conservation), parasites are often eradicated to reduce risks to captive populations (Stringer \& Linklater 2014). This systematic eradication has been responsible for the regional extirpation and extinction of parasites (Jørgensen 2014), which in some cases leads hosts to be more susceptible upon reintroduction. For example, when gray wolves were reintroduced to Yellowstone, the removal of parasitic mites increased the susceptibility of wolves to viral pathogens (Almberg et al. 2012). However, in addition to maintaining parasites that are beneficial to their host species, conservation efforts must treat endangered parasites of endangered hosts as worthwhile targets in their own right, supplanting the paradigm that parasite eradication is synonymous with disease control in threatened hosts. Fortunately, the costs of parasite eradications are well enough studied that current conservation best practices are perhaps more advanced in ex situ protocols than other parasite conservation tools. For example, the International Union for Conservation of $\mathrm{Na}$ ture Guidelines for Reintroductions and Other Conservation Translocations advocate for reintroducing parasites along with translocated hosts after a period of absence (Jørgensen 2014).

Despite these guidelines, most interest thus far has been on using parasite conservation as a tool for host preservation, and implementation strategies for critically endangered hosts are not formalized. Jørgensen (2014) highlights the potential for conflicts that arise when conserving several parasite species within a single host species, drawing on the case study of the host-specific louse, Felicola isidoroi, of the critically endangered Iberian lynx (Lynx pardinus). While captive breeding represents the best chance for $F$. isidoro $i$ to be saved, a plethora of disease-carrying generalist ectoparasites make delousing a requisite part of the lynx's conservation plan. Pérez et al. (2013) suggest extreme measures; to work around delousing, they recommend transferring $F$. isidoro $i$ by hand from wild lynx into captive breeding stock. As this example highlights, developing conservation plans that benefit both hosts and parasites of conservation interest requires attention to the broader ecological context.

Maintaining complex HPIs with proper environmental conditions for parasite transmission will likely be economically and spatially restrictive when hosts are being bred in captivity. For parasites that complement goals associated with a hosts' conservation, it may be easiest 


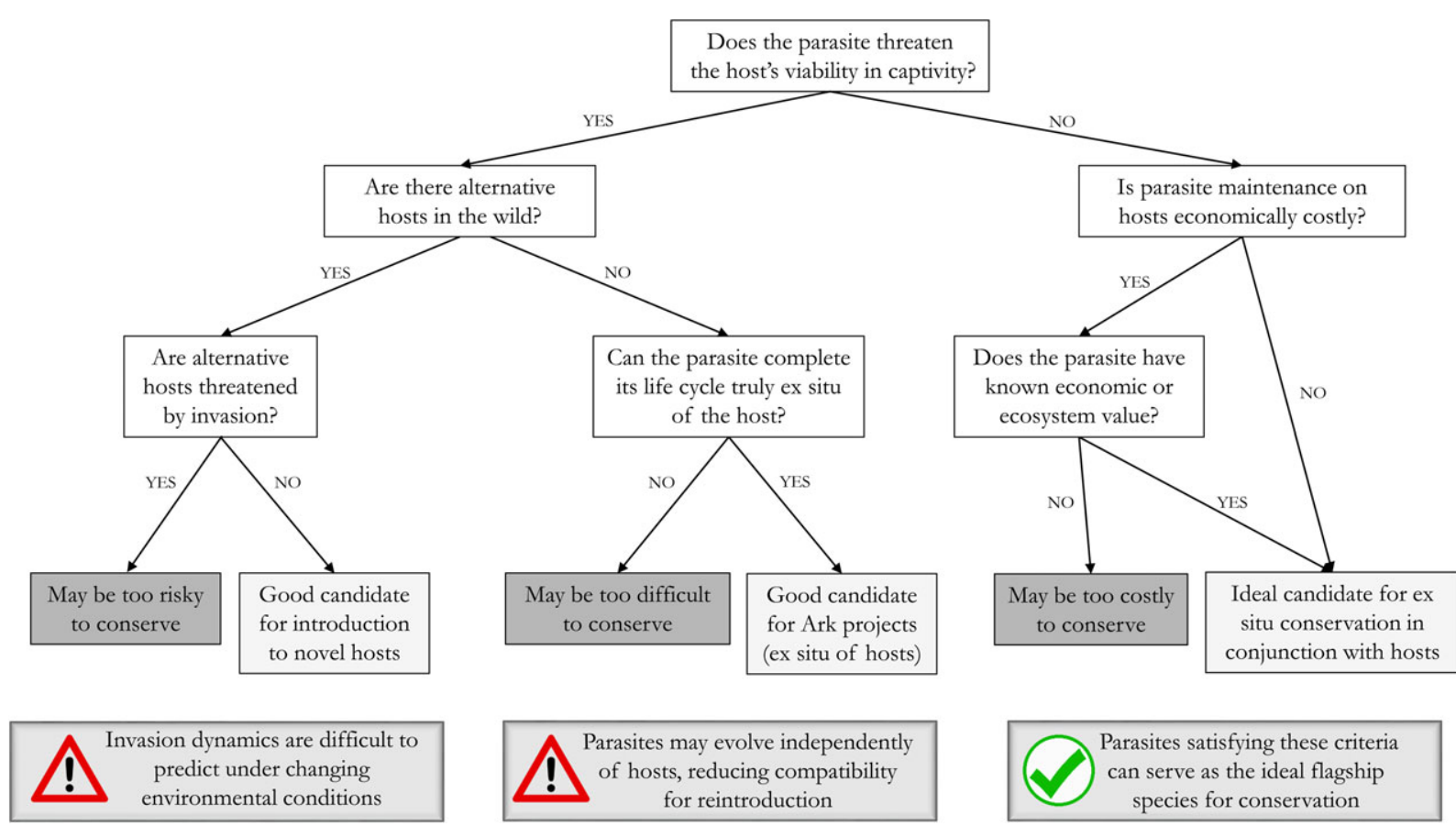

Figure 3. A cautious decision-making process for ex situ conservation of parasites that limits potential risks to hosts while maximizing the return on conservation investments.

to simply maintain them together in captive breeding programs. In situations where parasites cannot be feasibly maintained in captive host populations or established in phylogenetically related alternative hosts in the wild, options for truly ex situ conservation should be explored (Fig. 3) (Silverman et al. 2001). These may come in the form of ark projects (Soulé et al. 1986), in which the parasite is removed entirely from its host and supported using artificial methods. While we are not aware of any largescale projects of this sort, it is easy to conceive of a collection of in vitro adults (e.g., for readily cultured cestodes) or earlier developmental stages (e.g., eggs or protozoan cysts) similar to large seed bank projects. For the most limited groups, introduction into novel virgin hosts may be a last resort, although this may represent the riskiest strategy available for ex situ conservation of parasites.

The goal of any such effort should be reintroduction into natural host populations upon their recovery because maintaining parasites as museum species (i.e., species that only remain in zoos or laboratories) will be costly and only serve research purposes. However, due to our incomplete knowledge about the roles of specific parasites in their natural systems, ex situ conservation measures should be taken at every opportunity to maintain any parasite that cannot justifiably be conserved on its host.

Even in situations where ex situ conservation is successful, issues may arise surrounding reintroduction, namely, potentially divergent evolutionary trajectories between host and parasite and risk of invasion. Parasites evolve in conjunction with the internal environments of their hosts (Koskella \& Lively 2007). Hosts that have been living without a specific parasite could be colonized with other parasites that may outcompete the original organism upon reintroduction (Fenton \& Perkins 2010). Furthermore, hosts separated from their native parasite assemblage may then be especially susceptible to virulent infections by the reintroduced parasite (Aiello et al. 2014). Most megafauna conservation efforts that involve relocation of animals include deworming and vaccination of hosts (Cunningham 1996). We should instead establish protocols for maintaining both the internal and external environments of conserved megafauna species. These efforts should include consistent testing of introduced and potential native hosts to determine whether parasites are experiencing immunological release into new, naïve hosts (Cunningham 1996).

\section{Including Parasites in Open-Source Data Management Systems}

In developing a plan for parasite preservation, the allocation of limited conservation funds requires a triage system that includes hosts' environmental sensitivity. Yet, complex, multihost life cycles obscure the correlation in vulnerability between parasites and any given host. As the case of the Iberian lynx highlights, considering single host-parasite pairs is often insufficient to devise accurate conservation plans, and association data is required to inform conservation work. At a broader scale, 
understanding the risk parasites face from threats such as climate change or habitat loss requires information regarding distributions, prevalence, and host specificity that has never been compiled in one definitive source. Currently, long-term parasite ecology data sets are limited, and integration across platforms is virtually nonexistent. Major data sources like the Global Biodiversity Informatics Facility (www.gbif.org) and the Encyclopedia of Life (www.eol.org) decouple parasites from their hosts, and though parasite diversity databases exist, they tend to be specific to particular groups of hosts, especially at the class or order level (e.g., the Global Mammal Parasite Database [Nunn \& Altizer 2005], FishPEST [Strona \& Lafferty 2012], and the Global Cestode Database [Caira et al. 2012]). Some of the best databases are also worryingly out of date with respect to the rate of species description, such as the Host-Parasite Database curated by the British Natural History Museum, last updated in 2003 (Gibson et al. 2005).

Taxonomic data on host affiliations and phylogenetic relationships can help fill some of these gaps in parasite biology (Dunn et al. 2009; Rózsa \& Vas 2015). In cases where systematic data are inaccurate or poorly integrated, vulnerability assessments are correspondingly questionable. For instance, the louse Columbicola extinctus was believed to be endemic to the Passenger Pigeon (Ectopistes migratorius) and to have gone extinct (Stork \& Lyal 1993), but genetic data later revealed $C$. extinctus is extant on the Band-tailed Pigeon (Columba fasciata) (Clayton \& Price 1999). To solve some of these problems, online data repositories containing information on taxonomy should be integrated with host and parasite phylogenies.

Making existing spatial data more freely available to researchers in conjunction with existing open source databases and museum collections will also accelerate progress and reduce costs in time, money, and computing power. In particular, distributional data is still needed for the identification of biodiversity hotspots based on high levels of parasite richness and endemism (Myers et al. 2000). Existing efforts to catalogue host-parasite records in a spatially explicit manner are ongoing and incomplete. This process may benefit from collaboration with medical researchers, coopting infrastructure for monitoring important infectious diseases (e.g., the Gideon database [Smith et al. 2007]).

\section{Galvanizing Support for Parasite Conservation}

The vital first step in effectively incorporating parasites into existing conservation schemes is a shift in the minds of practitioners around the world. The success of parasite conservation programs, however, will be contingent upon extensive public outreach. We hope calling attention to parasite diversity will catalyze a shift much like the transformation of public perception of top carnivores. Just as wolves or big cats captivate the minds of school children, so too can the fungus that turns ants into zombies (Ophiocordyceps camponoti-balzani) or the isopod that eats and replaces the tongue of a fish (Cymothoa exigua). Though museums and zoos represent the primary means by which the public is exposed to global biodiversity, parasite collections are seldom displayed or receive little attention, reducing awareness and utility of these resources to non-parasitologists. The variety of parasite life styles represents an unparalleled evolutionary opportunism and creativity that constitutes a critical and unsung component of the diversity of life (though recent media coverage has stimulated discussions on this subject [Jones 2015]). At present, the conservation agenda expressed by academia and nongovernmental organizations overlooks this realm of biodiversity, making advocacy for parasite biodiversity intractable. Biodiversity is no longer a concept endemic to academic discussions; rather, it has become almost synonymous with the idea of nature itself and should be broadened to include parasites. Engaging the public on the importance of parasites and expanding conservation tools will bolster efforts to combat the greatest threats to biodiversity.

\section{Acknowledgments}

We especially thank A. Phillips and W. Getz, and the Brashares group at the University of California Berkeley for input on the development of the manuscript and F. De Amaral for help in the construction of figures. We also thank J. Flegal for her aid in editing. Finally, we greatly appreciate the 3 anonymous reviewers for extensive feedback and revisions.

\section{Literature Cited}

Aiello C, Nussear K, Walde A, Esque T, Emblidge P, Sah P, Bansal S, Hudson P. 2014. Disease dynamics during wildlife translocations: disruptions to the host population and potential consequences for transmission in desert tortoise contact networks. Animal Conservation 17(S1):27-39.

Almberg ES, Cross PC, Dobson AP, Smith DW, Hudson PJ. 2012. Parasite invasion following host reintroduction: a case study of Yellowstone's wolves. Philosophical Transactions of the Royal Society of London. Series B, Biological Sciences 367(1604) DOI: 10.1098/rstb.2011.0369.

Anderson RM, May RM. 1978. Regulation and stability of host-parasite population interactions: I. Regulatory processes. The Journal of Animal Ecology 47:219-247.

Barrett S. 2004. Eradication versus control: the economics of global infectious disease policies. Bulletin of the World Health Organization 82:683-688.

Berger J, Wehausen JD. 1991. Consequences of a mammalian predatorprey disequilibrium in the great basin desert. Conservation Biology 5:244-248.

Bergstrom R, Harrington LM, Ramsey D. 2013. Balancing communities, economies, and the environment in the greater Yellowstone ecosystem. Journal of Rural and Community Development 8:228-241. 
Boyce MS. 1992. Population viability analysis. Annual Review of Ecology and Systematics 23:481-506.

Caira J, Jensen K, Barbeau E. 2012. Global cestode database. Available from www.tapewormdb.uconn.edu (accessed July 2015).

Callahan K, Bolton B, Hopkins DR, Ruiz-Tiben E, Withers PC, Meagley K. 2013. Contributions of the guinea worm disease eradication campaign toward achievement of the millennium development goals. PLoS Neglected Tropical Diseases 7:e2160 DOI:10.1371/journal.pntd.0002160.

Clayton DH, Price RD. 1999. Taxonomy of new world Columbicola (Phthiraptera: Philopteridae) from the Columbiformes (Aves), with descriptions of five new species. Annals of the Entomological Society of America 92:675-685.

Corn JL, Nettles VF. 2001. Health protocol for translocation of freeranging elk. Journal of Wildlife Diseases 37:413-426.

Costello MJ, May RM, Stork NE. 2013. Can we name Earth's species before they go extinct? Science 339:413-416.

Cunningham AA. 1996. Disease risks of wildlife translocations. Conservation Biology 10:349-353.

Dennis B, Munholland PL, Scott JM. 1991. Estimation of growth and extinction parameters for endangered species. Ecological Monographs 61:115-143.

DeVault TL, Rhodes Jr OE, Shivik JA. 2003. Scavenging by vertebrates: behavioral, ecological, and evolutionary perspectives on an important energy transfer pathway in terrestrial ecosystems. Oikos 102:225-234.

Dunn RR, Harris NC, Colwell RK, Koh LP, Sodhi NS. 2009. The sixth mass coextinction: Are most endangered species parasites and mutualists? Proceedings of the Royal Society of London B: Biological Sciences 276(1670) DOI: 10.1098/rspb.2009.0413

Fenton A, Perkins SE. 2010. Applying predator-prey theory to modelling immune-mediated, within-host interspecific parasite interactions. Parasitology 137:1027-1038.

Gerber LR, McCallum H, Lafferty KD, Sabo JL, Dobson A. 2005. Exposing extinction risk analysis to pathogens: Is disease just another form of density dependence? Ecological Applications 15:1402-1414.

Gibson D, Bray R, Harris E. 2005. Host-parasite database of the Natural History Museum, London. Available from http://www.nhm. ac.uk/host-parasites/database (accessed July 2015).

Gómez A, Nichols E. 2013. Neglected wild life: parasitic biodiversity as a conservation target. International Journal for Parasitology: Parasites and Wildlife 2:222-227.

Gompper ME, Williams ES. 1998. Parasite conservation and the blackfooted ferret recovery program. Conservation Biology 12:730-732.

Hairston NG, Smith FE, Slobodkin LB. 1960. Community structure, population control, and competition. The American Naturalist 94:421425.

Hatcher MJ, Dick JT, Dunn AM. 2012. Diverse effects of parasites in ecosystems: linking interdependent processes. Frontiers in Ecology and the Environment 10:186-194.

Izdebska JN. 2006. Skin mites (acari: Demodecidae, psoroptidae, and sarcoptidae) of the european bison, bison bonasus. Biological Letters 43(2):169-174.

Johnson PT, Preston DL, Hoverman JT, LaFonte BE. 2013. Host and parasite diversity jointly control disease risk in complex communities. Proceedings of the National Academy of Sciences 110:1691616921.

Jones L. 2015. What would happen if all the parasites disappeared? BBC, London. Available from http://www.bbc. com/earth/story/20150127-what-if-all-the-pests-vanished (accessed July 2015).

Jørgensen D. 2014. Conservation implications of parasite coreintroduction. Conservation Biology 29:602-604.

Kamath PL, Turner WC, Kusters M, Getz WM. 2014. Parasite-mediated selection drives an immunogenetic trade-off in plains zebras (Equus Quagga). Proceedings of the Royal Society of London B: Biological Sciences 281(1783): DOI: 10.1098/rspb.2014.0077.
Kellert SR, Black M, Rush CR, Bath AJ. 1996. Human culture and large carnivore conservation in north america. Conservation Biology 10:977-990.

Koh LP, Dunn RR, Sodhi NS, Colwell RK, Proctor HC, Smith VS. 2004. Species coextinctions and the biodiversity crisis. Science 305:16321634.

Koskella B, Lively CM. 2007. Advice of the rose: experimental coevolution of a trematode parasite and its snail host. Evolution 61:152-159.

Kuris AM. 2012. The global burden of human parasites: Who and where are they? How are they transmitted? The Journal of Parasitology 98:1056-1064.

Kuris AM, et al. 2008. Ecosystem energetic implications of parasite and free-living biomass in three estuaries. Nature 454:515-518.

Lafferty KD. 2014. Biodiversity loss and infectious diseases. Pages 73-89 in Verdade LM, Lyra-Jorge MC, Piña CI, editors. Applied ecology and human dimensions in biological conservation. Springer, New York.

Lafferty KD, et al. 2008. Parasites in food webs: the ultimate missing links. Ecology Letters 11:533-546.

Lafferty KD, Dobson AP, Kuris AM. 2006. Parasites dominate food web links. Proceedings of the National Academy of Sciences 103:1121111216 .

Lafferty KD, Kuris A. 2014. Ecological consequences of host manipulation by parasites. Integrative and Comparative Biology 54:E117E117.

Lefevre T, Lebarbenchon C, Gauthier-Clerc M, Misse D, Poulin R, Thomas F. 2009. The ecological significance of manipulative parasites. Trends in Ecology \& Evolution 24:41-48.

Mariner JC, House JA, Mebus CA, Sollod AE, Chibeu D, Jones BA, Roeder PL, Admassu B, van 't Klooster GG. 2012. Rinderpest eradication: appropriate technology and social innovations. Science 337:13091312.

Mech LD, Boitani L. 2010. Wolves: behavior, ecology, and conservation: behavior, ecology, and conservation. University of Chicago Press, Chicago.

Messmer TA, Brunson MW, Reiter D, Hewitt DG. 1999. United States public attitudes regarding predators and their management to enhance avian recruitment. Wildlife Society Bulletin 27:75-85.

Mougi A, Kondoh M. 2012. Diversity of interaction types and ecological community stability. Science 337:349-351.

Myers N, Mittermeier RA, Mittermeier CG, Da Fonseca GA, Kent J. 2000. Biodiversity hotspots for conservation priorities. Nature 403:853858.

Nunn CL, Altizer SM. 2005. The global mammal parasite database: an online resource for infectious disease records in wild primates. Evolutionary Anthropology: Issues, News, and Reviews 14:1-2.

Pérez JM, Sánchez I, Palma RL. 2013. The dilemma of conserving parasites: the case of Felicola (Lorisicola) isidoroi (Phthiraptera: Trichodectidae) and its host, the endangered Iberian lynx (Lynx pardinus). Insect Conservation and Diversity 6:680-686.

Pizzi R. 2009. Veterinarians and taxonomic chauvinism: the dilemma of parasite conservation. Journal of Exotic Pet Medicine 18:279-282.

Poulin R. 2010. Parasite manipulation of host behavior: an update and frequently asked questions. Advances in the Study of Behavior 41:151-186.

Ray J, Redford KH, Steneck R, Berger J. 2013. Large carnivores and the conservation of biodiversity. Island Press, Washington, D.C.

Rohlf DJ. 1991. Six biological reasons why the endangered species act doesn't work-and what to do about it. Conservation Biology 5: 273-282.

Rózsa L, Vas Z. 2015. Co-extinct and critically co-endangered species of parasitic lice, and conservation-induced extinction: Should lice be reintroduced to their hosts? Oryx 49:107-110.

Rudolf V, Lafferty KD. 2011. Stage structure alters how complexity affects stability of ecological networks. Ecology Letters 14:75-79.

Sato T, Watanabe K, Kanaiwa M, Niizuma Y, Harada Y, Lafferty KD. 2011. Nematomorph parasites drive energy flow through a riparian ecosystem. Ecology 92:201-207. 
Sergio F, Caro T, Brown D, Clucas B, Hunter J, Ketchum J, McHugh K, Hiraldo F. 2008. Top predators as conservation tools: ecological rationale, assumptions, and efficacy. Annual Review of Ecology, Evolution, and Systematics 39:1-19.

Silverman AL, Qu LH, Blow J, Zitron IM, Gordon SC, Walker ED. 2001. Assessment of hepatitis B virus DNA and hepatitis C virus RNA in the common bedbug (Cimex lectularius L.) and kissing bug (Rodnius prolixus). The American Journal of Gastroenterology 96:21942198.

Smith KF, Sax DF, Gaines SD, Guernier V, Guégan J. 2007. Globalization of human infectious disease. Ecology 88:1903-1910.

Soulé M, Gilpin M, Conway W, Foose T. 1986. The millenium ark: How long a voyage, how many staterooms, how many passengers? Zoo Biology 5:101-113.

Stork NE, Lyal CH. 1993. Extinction or 'co-extinction' rates? Nature 366:307.
Stringer AP, Linklater W. 2014. Everything in moderation: principles of parasite control for wildlife conservation. Bioscience 64: 932-937.

Strona G, Lafferty KD. 2012. FishPEST: an innovative software suite for fish parasitologists. Trends in Parasitology 28:123.

Summers RW, Elliott DE, Urban Jr JF, Thompson R, Weinstock JV. 2005. Trichuris suis therapy in Crohn's disease. Gut 54: 87-90.

White PC, Gregory KW, Lindley PJ, Richards G. 1997. Economic values of threatened mammals in britain: a case study of the otter Lutra lutra and the water vole Arvicola terrestris. Biological Conservation 82:345-354.

Yazdanbakhsh M, Kremsner PG, van Ree R. 2002. Allergy, parasites, and the hygiene hypothesis. Science 296:490-494.

Zhang J, Daszak P, Huang H, Yang G, Kilpatrick AM, Zhang S. 2008. Parasite threat to panda conservation. Ecohealth 5:6-9.

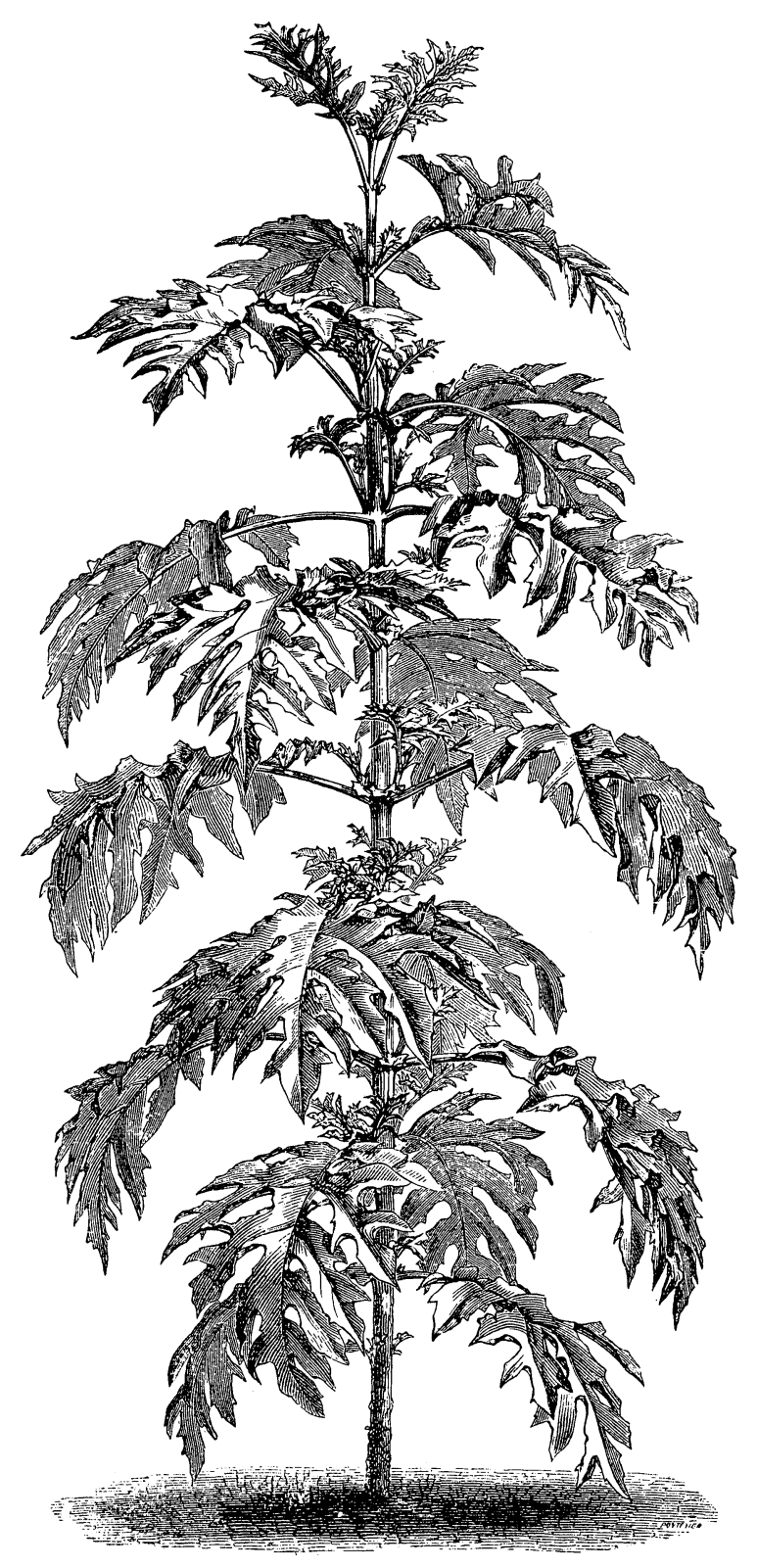

